\title{
Effect of Microstructure on Grindability in Alumina Ceramics
}

\author{
Yoshihito KONDO, Yasuyuki KUROSHIMA, Akira TSUKUDA \\ and Shōjirō OKADA \\ (Kagawa Prefectural Industrial Technology Center) \\ Gōtō-chō, Takamatsu-shi 761
}

\section{アルミナセラミックスの被研削性に及ぼす微細構造の影響}

近藤祥人・黒島泰幸・佃昭・岡田昭次郎

(香川県工業技術センター)

\begin{abstract}
Alumina ceramics, the most universal modern ceramic materials, generally require a grinding process. There are so many kinds of alumina ceramics of which proper grinding conditions have not yet been established. In this study, test pieces of alumina ceramics were made by sintering at various temperatures and ground by a diamond grinding wheel in order to investigate the relation between the microstructure and the grindability. The results showed that alumina ceramics with $4 \mu m$-grain were the most difficult to grind because of the maximum toughness and that those of larger grains were easy to grind because of the ease of the chip removal.

[Received February 14, 1986]
\end{abstract}

Key-words : Alumina ceramics, Grindability, Microstructure, Grain size, Grinding force

Up to the present, alumina ceramics play a major role among various kinds of ceramic materials because of their good physical properties and low price in both electronic and engineering fields. Grinding process is essential for this kind of ceramics to give them both necessary shape and surface integrity.

As far as a diamond grinding wheel is used, alumina ceramics are not always "difficult to grind material" but there exist large variations in grindability. In order to grind the modern ceramic materials at high material removal rate, several works were reported on a new diamond grinding wheel of more efficient cutting ability ${ }^{1)}$ and on the grindability of such materials ${ }^{2)}$.

This work suggests the relation between microstructure and grindability in the various kinds of alumina ceramics.

As to the raw material for the specimens the alumina powder with $\mathrm{Al}_{2} \mathrm{O}_{3}$ content of $99.5 \%$ and grain size of $0.6 \mu \mathrm{m}$ (Shōwa Keikinzoku Co., AL-160 SG) was adopted. After this powder was mixed with $3 \mathrm{wt} \%$ binder (Chūkyō Yushi Co., $\mathrm{D}-830$ ), the mix was granulated to $80 \mu \mathrm{m}$ particle size using a spray-dryer and then pressed under $800 \mathrm{kgf} / \mathrm{cm}^{2}$. The pressed green specimens were heated at a rate of $300^{\circ} \mathrm{C} / \mathrm{h}$ up to $1450^{\circ}(\mathrm{A})$,
$1500^{\circ}(\mathrm{B}), 1550^{\circ}(\mathrm{C}), 1600^{\circ} \mathrm{C}(\mathrm{D})$, respectively and then kept heating for $3 \mathrm{~h}$.

In general, the grindability of ceramics is empirically estimated with the value of MOR (modulus of resilience), which is expressed as $\mathrm{MOR}=\sigma_{\mathrm{t}}^{2} / 2 E$

where $\sigma_{\mathrm{t}}$ is tensile strength $\left(\mathrm{kgf} / \mathrm{mm}^{2}\right)$ and $E$ is Young's modulus $\left(\mathrm{kgf} / \mathrm{mm}^{2}\right)$.

Grinding test was carried out using a vitrified diamond grinding wheel according to the following grinding condition.

(a) grinding machine : horizontal spindle resiprocating table surface grinding machine (Type Okamoto PSG-52 A, 2.2 KW)

( $b$ ) method of grinding : surface grinding of plunge cut type

(c) grinding wheel : D 170 L 75 VG, straight wheel, $180 \mathrm{~mm}$ diameter $\times 10 \mathrm{~mm}$ thickness $\times$ $31.75 \mathrm{~mm}$ hole diameter

(d) peripheral wheel speed : $1600 \mathrm{~m} / \mathrm{min}$

(e ) table speed : $10 \mathrm{~m} / \mathrm{min}$

(f) down feed rate : $10 \mu \mathrm{m} /$ pass

(g) coolant : water soluble type W-2, 10 $1 / \min$

(h) dressing : vitrified silicon carbide (\# 180) rotary wheel

It is said that both components of grinding 
Table 1. The properties of alumina ceramics,

\begin{tabular}{ccccccc}
\hline $\begin{array}{r}\text { Sample Apparent Bending } \\
\text { density }\end{array}$ & $\begin{array}{c}\text { Young's } \\
\text { modulus } \\
\left(\mathrm{g} / \mathrm{cm}^{3}\right)\end{array}$ & $\begin{array}{c}\text { MOR } \\
\left(\mathrm{kgf} / \mathrm{mm}^{2}\right)\end{array}$ & $\begin{array}{c}\text { Knoop } \\
\left(\mathrm{kg} / 0^{4} / \mathrm{mm}^{2}\right)\end{array}$ & $\begin{array}{c}\text { Grain } 10^{-2} \\
\left(\mathrm{kgf} \cdot \mathrm{mm}^{-2} \mathrm{~mm}^{3}\right)\end{array}$ & $\begin{array}{c}\text { haraness } \\
\text { size }\end{array}$ & $(\mu \mathrm{m})$ \\
\hline A & 3.44 & 26.9 & 2.60 & 1.39 & - & 1 \\
B & 3.68 & 34.8 & 3.26 & 1.86 & 1520 & 2.5 \\
C & 3.84 & 43.3 & 3.76 & 2.47 & 1626 & 4 \\
D & 3.87 & 42.8 & 3.85 & 2.38 & 1783 & 6 \\
\hline
\end{tabular}

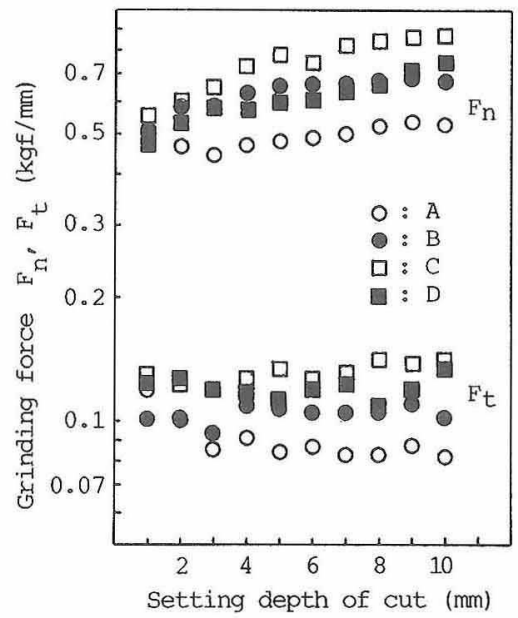

Fig. 1. Change of grinding force.

force, i.e. tangential $F_{\mathrm{t}}$ and normal $F_{\mathrm{n}}$ are the most appropriate standard to evaluate the grindability. Grinding force was measured during grinding down to $10 \mathrm{~mm}$ grinding depth. The properties of the said ceramics are listed in Table 1. The grinding force during grinding is shown in Fig. 1.

Figure 1 represents that the normal force increases with grinding time and that the tangential force keeps constant. As compared with other modern ceramics such as $\mathrm{Si}_{3} \mathrm{~N}_{4}$, the tangential force of alumina ceramics is remarkably smallit. The normal force originates with the thrust force against work piece and relates to the elastic displacement and accumulated stress throughout the grinding system. Increasing tendency of normal force means that the cutting edge of diamond wears out by hard alumina ceramics attritiously and it results in insufficient dimensional accuracy and chatter vibration. In case of grinding of alumina ceramics, the grinding wheel and machine must have enough stiffness. The tangential force relates directly to the energy for the chip removal and therefore the reduced tangential force means that the grinding is performed very freely. From this point of view, alumina ceramics seem to be rather "easy

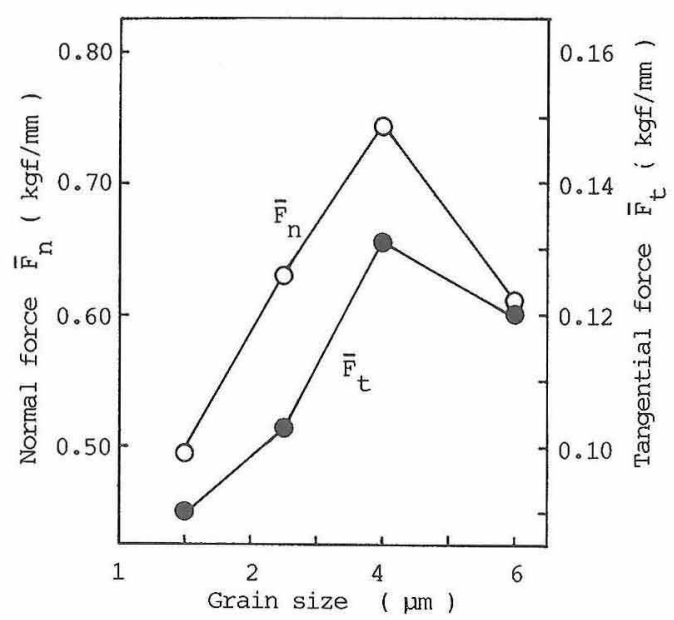

Fig. 2. The relation between grain size and grinding force.

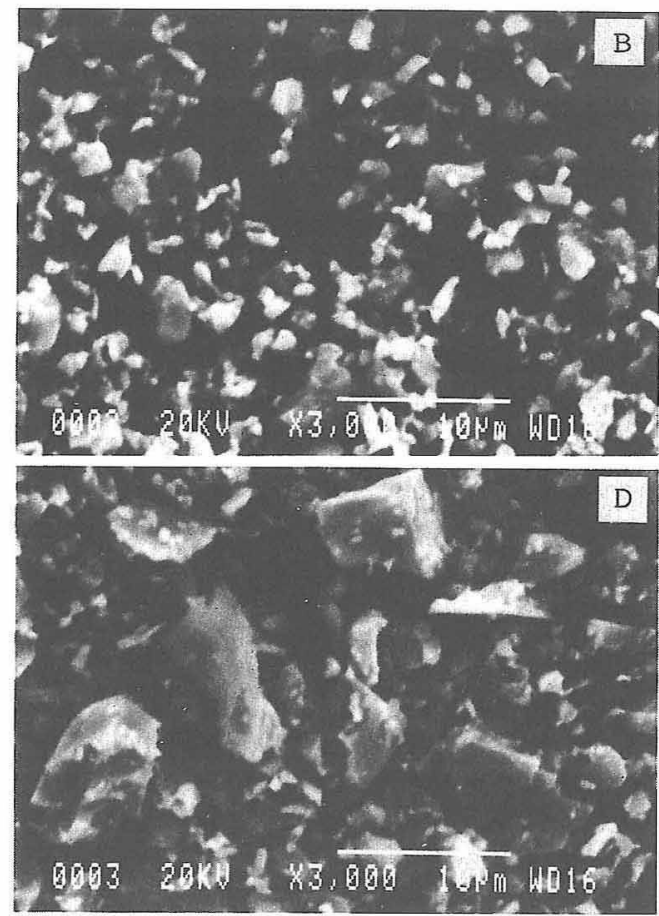

Fig. 3. The SEM photographies of chips on grinding process.

to grind material" than "difficult to grind material".

Figure 2 indicates the relation of the grinding force to the grain size. Both $F_{\mathrm{n}}$ and $F_{\mathrm{t}}$ increase in proportion as the grain size increases up to 4 $\mu \mathrm{m}$ and then decrease with further increasing grain size.

Figure 3 indicates the SEM photographies of the chips evacuated from the ceramics. It is seen that the chip of sample D is larger than that 
of sample B, because alumina ceramics of larger grain size are, independent of the toughness, easily scraped out as a chip.

It is concluded within a scope of the experiments described above that the grindability of alumina ceramics whose grain size is smaller than $4 \mu \mathrm{m}$ especially conforms to the MOR theory. Where grain size exceeds $4 \mu \mathrm{m}$, it becomes easier to grind, because in alumima cera- mics composed of large grains the cracks are easily extended promoting chip evacuation.

\section{References}

1) Y. Kuroshima, Y. Kondo and S. Okada, Yogyo-KyokaiShi, 93, 587-89 (1985)

2) B. G. Koepke and R. J. Stokes, NBS Special Pub., 562, 75-91.

3) Y. Kondo, Y. Kuroshima, A. Tsukuda and S. Okada, Yogyo-Kyokai-Shi, 94, 201-03 (1986). 